ZOOLOGIA 32 (2): 93-108, April 2015

http://dx.doi.org/10.1590/S1984-46702015000200001

\title{
Richness, breeding environments and calling activity of the anurofauna of the lower moa river forest, state of Acre, Brazil
}

\author{
Daniele B. Miranda ${ }^{1,4}$, Saymon de Albuquerque ${ }^{2}$, Luiz Carlos B. Turci ${ }^{3} \&$ Paulo S. Bernarde $^{3}$ \\ 'Instituto Federal de Educação, Ciência e Tecnologia de Rondônia. Rua Rio Amazonas 151, Jardim dos Migrantes, \\ 76900-730 Ji-Paraná, RO, Brazil. \\ ${ }^{2}$ Departamento de Zoologia, Centro de Ensino Faculdade São Lucas. Rua Alexandre Guimarães 1927, Areal, \\ 76804-373 Porto Velho, RO, Brazil. \\ ${ }^{3}$ Laboratório de Herpetologia, Centro Multidisciplinar, Universidade Federal do Acre. Campus Floresta, 69980-000 Cruzeiro \\ do Sul, AC, Brazil. \\ ${ }^{4}$ Corresponding author. E-mail: daniele_bm@yahoo.com.br
}

\begin{abstract}
In state of Acre, most anuran research has been carried out in areas of terra firme, whereas alluvial forests remain relatively unexplored. We document the richness, breeding environments and calling season of the anurans of the Lower Moa River in the Alto Juruá (state of Acre), a region considered to harbor high biodiversity. Sampling was conducted in two main areas with different forest typologies (Terra firme forest and Alluvial forest), totaling 256 ha. The diversity of anurans was analyzed using the Shannon-Wiener index, evenness and Berger - Parker dominance. The anurans were sampled from October 2008 to September 2009, using the following sampling methods: sampling at breeding sites, pitfall traps, time constrained visual search during the day (TCVSD); at night (NVTCS) and active search (AS). Fifty anuran species, belonging to eight families, were recorded: Aromobatidae (2), Bufonidae (5), Hemiphractidae (1), Hylidae (25), Leptodactylidae (9), Microhylidae (4), Ranidae (1) and Craugastoridae (3). Pitfall traps totaling 1440 day-buckets in the year. DVTCS had a total sampling effort 72 hours/person/year; NVTCS - 72 hours/person/year and AS - 24 hours/person/ year. Greater richness (35 species) was recorded in the alluvial forest, low diversity index and high dominance $\left(\mathrm{H}^{\prime}=1.69\right.$, $J^{\prime}=0.51, d=0.62$ ). Most likely, these values were influenced by the high relative abundance of Rhinella margaritifera in this area. The richness of the alluvial forest may be associated with environmental heterogeneity according with the theory of intermediate disturbances. The breeding activity of most species occurred in lentic environments (lakes and temporary ponds) and during the rainy season. When sampling anurans in the Amazon it is important to use two or more sampling method and to consider the different forest typologies of this biome for a better characterization of its richness.
\end{abstract}

KEY WORDS. Amazon; Amphibia; biodiversity; terra firme forest; alluvial forest.

Tropical forests, particularly those in the Neotropical region, contain a high diversity of anuran species (DuelLman 1999, HADDAD et al. 2013). More specifically, the diversity of amphibians in the Brazilian Amazon is poorly documented, since only a few regions have been sampled and literature data is scare (Avila-Pires et al. 2007).

Community ecology tries to identify the mechanisms that organize the distribution of species. The distribution of anuran species is influenced by abiotic and biotic factors such as climate and vegetation type (Duelman 1999). Research on anurans in the Amazon have been primarily conducted in areas of terra firme. Very little is known about the diversity of alluvial rivers, although there are reports of high numbers of species in wetlands or floodplain areas (Hödl 1977, Rodriguez \& Cadle 1990, Rodriguez 1992, Duellman \& Mendelson III 1995, May et al. 2009). Few studies have been conducted on the fauna of anurans of the Brazilian state of Acre (e.g., SouZA 2009, Bernarde et al. 2011, 2013). One survey of the Alto Juruá region (Souza 2009) found 124 species in the Serra do Divisor National Park, which has since become one of the richest regions in the world in terms of anuran species. Overall, studies on the anurans of Acre include new species descriptions (e.g., Martins \& Cardoso 1987, Caldwell \& Araújo 2005), studies on calling activity (e.g., Cardoso \& Vielliard 1990), reports of predation (e.g., Bernarde et al. 1999), and observations on parental care (e.g., Caldwell \& Oliveira 1999). In view of the insufficient knowledge concerning the anurans inhabiting Acre and alluvial forests in general, we endeavored to study frog richness, breeding areas and calling seasons in two forest types (terra firme forest and alluvial forest) of the Lower Moa River in the Alto Juruá region. Additionally, we compare both areas with Shannon-Wiener index, evenness, Berger - Parker dominance and abundance.

2015 | Sociedade Brasileira de Zoologia | www.sbzoologia.org.br | www.scielo.br/zool All content of the journal, except where identified, is licensed under a Creative Commons attribution-type BY-NC. 


\section{MATERIAL AND METHODS}

The forest of the Lower Moa River $\left(07^{\circ} 38^{\prime} 23.9^{\prime \prime} S\right.$, $\left.72^{\circ} 47^{\prime} 43.1^{\prime \prime} \mathrm{W}\right)$ is located in the municipality of Cruzeiro do Sul (state of Acre), $20 \mathrm{~km}$ from the town, along Highway AC 405. The Moa River is a tributary of the Juruá River, and is located in the extreme West of Brazil (ACRE 2006). Open Ombrophilous Forest predominates in the landscape (SILVeIRA et al. 2002), which is characterized by open canopy with palm trees, vines and/or bamboo (Veloso et al. 1991). The climate is tropical, hot and humid, with average annual temperature of $24^{\circ} \mathrm{C}$ (Ribeiro 1977). The driest period occurs between June and September. The annual rainfall ranges between 1,140 and 2,700 $\mathrm{mm}$. The relative humidity is always above $60 \%$. The climate of the Upper Juruá is more humid than in most of the Brazilian Amazon, with two rainy seasons, one with more rain and the other with less rain, resembling the super humid climate of the eastern Andean piedmont (DaLY \& Silveira 2002). For the purpose of this research, the rainy season was defined as the period between October 2008 to March 2009 and the "dry" season between April 2009 and September 2009. Sampling was conducted in two main areas with different forest structures and typologies, totaling 256 ha.

Alluvial forest area (AF) - Dense alluvial forest with emergent trees (Fig. 1). This forest typology is found along the major rivers and some of their tributaries (ACRE 2006). It is strongly influenced by the proximity of the Moa River, which determines seasonal floods and water input to the lakes. The forest canopy has trees with an average height of $20 \mathrm{~m}$, but some trees may reach a height of $35 \mathrm{~m}$. There is a trail through the forest. This trail gets flooded during the wet season due to the influence of the Moa River and borders an abandoned meander that forms three lakes (January-March). The formation of temporary ponds and waterlogged environments inside the forest in the beginning of the rainy season is common. Also, temporary ponds at the forest edge form between the alluvial forest and the pasture area.

Terra firme forest area (TFF) - Open terra firme forest with palms (Fig. 2). This vegetation is generally found in areas near alluvial floodplains, and is characterized by an open canopy forest with palm trees and vines (ACRE 2006). There is high water flow in the wet season. In the study area, a temporary stream (igarapé), about $3 \mathrm{~m}$ wide, dries out seasonally and is bordered by a trail along its length. Temporary ponds in forest environments and at the forest edge are common in the rainy months. Similarly, temporary ponds at the forest edge also occur near pasture areas. More details about the vegetation of both areas can be found in Bernade et al. 2013.

The anurans were sampled from October 2008 to September 2009, using the following sampling methods:

1) Sampling at breeding sites (SBS) (HEYER et al. 1994) consisted of looking for amphibians in aquatic environments (rivers, streams, abandoned meanders, temporary ponds, etc.) by means of aural records (AR) or visual records. This sampling method was applied each month for three days in the alluvial forest area and three days in the terra firme forest area (mornings 8:00 a.m. to 10:00 a.m. and nights 7:00 p.m. to 11:00 p.m.), totaling 36 days in one year in each area. Since this methodology was only used to complement the number of species recorded in the Lower Moa River, the total sampling effort per person was not calculated.

2) Pitfall traps (PFT) (CoRn 1994), following the recommendations of CeChin \& Martins (2000). These traps consist of containers (buckets or barrels) buried in the ground and interconnected by a fence guide (canvas or plastic screen). Each trap, composed of four $100 \mathrm{~L}$ plastic buckets, was buried every 10 meters and connected by a $1 \mathrm{~m}$ high canvas fence. Ten trap sequences were built at least $100 \mathrm{~m}$ apart, five sequences with the buckets arranged in a straight line and five sequences arranged in a Y-shape, with one central bucket and three buckets disposed radially. Traps were installed in the open palm terra firme forest, and remained open three days per month for 12 months. Traps were monitored daily, totaling 36 days in one year or 1440 day-buckets in one year.

3) Visual time constrained search (VTCS) (CAMPBell \& Christman 1982). This consists of walking slowly on trails or transects within the forest, looking for anurans that are visually exposed, on all visually accessible microhabitats (ground, fallen logs, vegetation, etc.). Two $400 \mathrm{~m}$ long transects were selected for this, one located in the open terra firme forest with palm trees and the other in the alluvial forest with emergent trees. Search was carried out during the day (DVTCS) and at night (NVTCS). The DVTCS was conducted for one hour in each transect (between 8:00 a.m. to 11:00 a.m.), by three persons, totaling three hours in each area, six hours a month in both areas and 72 hours over the year. The sampling effort per person was 24 hours/person/year. The NVTCS lasted four hours in each transect (between 7:00 p.m. to 10:00 p.m.). It was conducted by four persons, totaling 12 hours in each area, 24 hours a month in both areas and 288 hours per year. The total sampling effort was 72 hours/person/year.

4) Active Search (AS) (Heyer et al. 1994). This included searching for anurans in all possible microenvironments, by disturbing the leaf litter, raising fallen logs, looking inside tree bark and under stones, inspecting epiphytes, holes in the ground and hollow trees. This method differs from the VTCS in that it includes inspection of the environment. Two people were involved and they searched for anurans only during the day (between 8:00 a.m. and 11:00 a.m.), totaling two hours in each type of forest, four hours per month and 48 hours per year. The total sampling effort was 24 hours/person/year.

\section{Data Analysis}

To examine the breeding environments used by the anurans, five types of environments were named and character- 

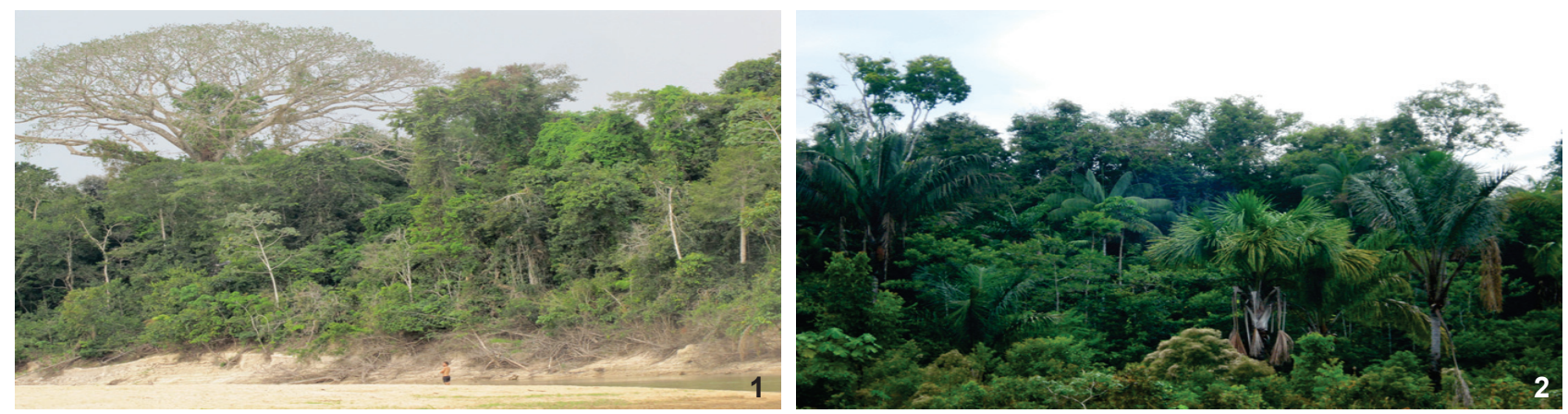

Figures 1-2. (1) Dense alluvial forest with emergent trees (Alluvial forest); (2) Open terra firme forest with palms (Terra firme forest).

ized in forested areas and forest edges, as follows: 1) Temporary Igarapé (TI): a narrow $(3 \mathrm{~m})$ and shallow $(60 \mathrm{~m})$ water course that crosses the terra firme forest, dries out seasonally, and has dark water running slowly during the rainy season. 2) Abandoned Meander (AM): ancient winding stretch of the Moa River that has become disconnected from the main channel and now forms a U-shaped lake, which fills up with water every year during the rainy season when the Moa River floods. The lake is located within the alluvial forest with emergent trees. 3) Temporary Ponds in Forested environment (TPF): Small $\left(1 \mathrm{~m}^{2}\right)$ to medium $\left(3 \mathrm{~m}^{2}\right)$ sized ponds formed inside the forest during the rainy season, and found in both forested areas. 4) Temporary ponds at the forest Edge (TPE): ponds formed from the accumulation of rainwater, located at the edge of the terra firme forest, within the grazing area. Marginal vegetation consists mainly of grasses, but trees, shrubs and palms are also found. 5) Waterlogged Environment (WE): accumulation of water in the soil which does not form ponds and is very common in the alluvial forest at the beginning or end of the flood season.

To study the use of environmental resources by anurans, the types of substrates in which the species were found and their vertical distribution (height in centimeters) were analyzed. The substrates were classified as follows: ground (GO) - ground without the presence of leaf litter found along the forest edge; grasses (GR) - plants from the family Poaceae, grasses that are quite common in the forest edge; leaf litter (LL) - layers of leaves covering the forest floor; woody vegetation (WV) - large trees with $\mathrm{DBH}>5 \mathrm{~cm}$ and height $>2$ meters; shrubs $(\mathrm{SB})-$ small plants, branched, with $\mathrm{DBH}<10 \mathrm{~cm}$ and height $<2 \mathrm{~m}$; herbaceous vegetation (HV) - plants with a soft and pliable stem without the presence of lignin, known as herbs; vines (VI) - plants rooted in the ground and that use other trees for support, also called lianas, which are very common in the forest canopy; palms (PA) - plants of the family Arecaceae (buriti, paxiubão, paxiubinha, maraja, joari, acai, among others); fallen branches and logs (BL) - pieces of trees found naturally on the ground; seedlings (SE) developing plant embryo, very common on the ground of tropical forests; aquatic vegetation (AV) - present in lakes formed by abandoned meanders, this floating vegetation is mainly charac- terized by the presence of Pistia stratiotes. The following were documented as evidence of reproduction: couples in amplexus, ovulating females, imagoes, juveniles and, in the case of the genus Allobates, tadpoles on the backs of adults.

The comparison between terra firme forest and alluvial forest was analyzed only with methodologies applied to the same sampling effort in both places: Visual time constrained search during the day (DVTCS), at night (NVTCS) and active search (AS)

The diversity of anurans in the terra firme forest and alluvial forest was analyzed using the Shannon-Wiener index, Evenness (Krebs 1999) and Berger - Parker dominance (MagurRan 1988). The Shannon index is one of most popular diversity statistics and it is sensitive to rare species and abundance variations. The Berger - Parker index provides a simple and easily interpretable measure of dominance (MAGURRAN 1988). The difference in abundance between the terra firme forest and the alluvial forest, which was calculated using the total species abundance of each sampled month, was analyzed using the chi-square test (ZAR 1999).

The influence of environmental variables (rainfall and temperature) on anuran calling activity was analyzed by applying the Spearman correlation coefficient (rs) (ZAR 1999). These data were from Cruzeiro do Sul (state of Acre), obtained from the National Institute of Meteorology (INMET).

All analyses were performed using the statistical programs BioEstat 4.0 (Ayres et al. 2005) and BioDiversity Professional 2.0 (MCalecee et al. 1997).

The species accumulation curve was estimated based on the monthly abundance of species and it was calculated by extrapolating the curves of accumulation by Jackknife index with 100 random additions in the program EstimateS 9.1.0 (Colwell 2013).

All collected specimens were fixed using recommended techniques (e.g., Bernarde 2012) and were deposited in the Herpetological Collection of the Federal University of Acre Campus Floresta (UFACF) located in Cruzeiro do Sul, state of Acre (IBAMA License 12178-1 and 12178-2). The taxonomy of anurans species follows Frost (2014). 


\section{RESULTS}

\section{Richness and Diversity}

Fifty species of anurans were recorded, belonging to eight families: Aromobatidae (2), Bufonidae (5), Hemiphractidae (1), Hylidae (25), Leptodactylidae (9), Microhylidae (4), Ranidae (1) and Craugastoridae (Table 1).

The randomizations performed on the species accumulation curve obtained for each area showed a gradual increase and reached the asymptote with little difference between alluvial forest and terra firme forest. The richness of the alluvial forest was estimated at 33 species and of the terra firme forest was 28 species (Figs. 3 and 4).
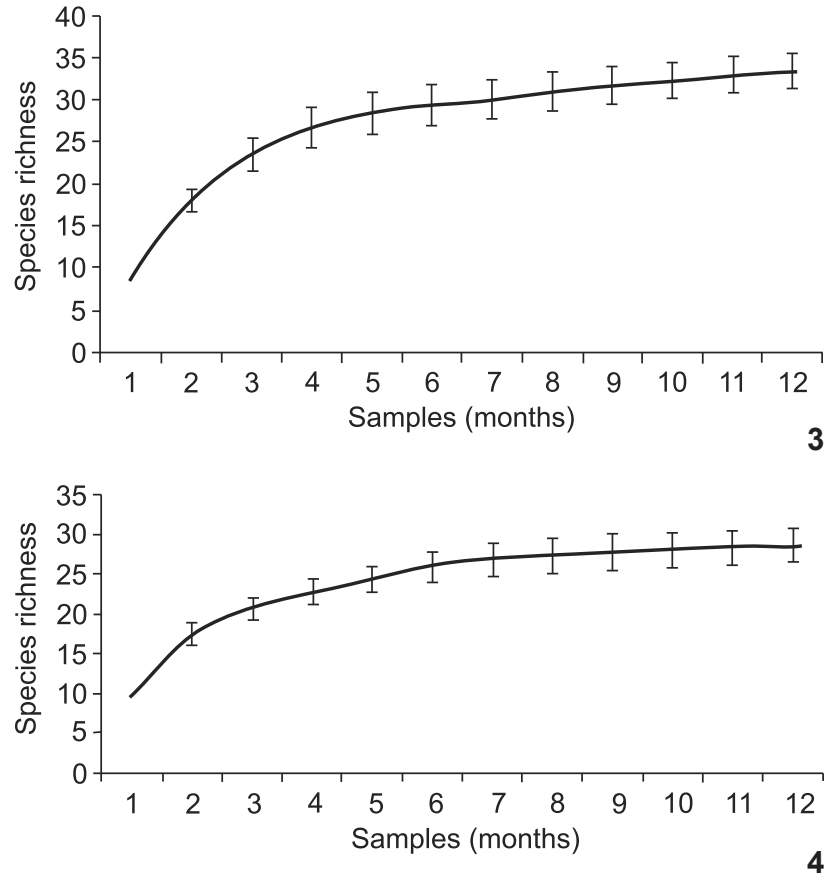

Figures 3-4. Accumulated curve of species from frogs in the Lower Moa River forest (AC), from October 2008 to September 2009. Data with 100 random samples additions: (3) Alluvial forest, (4) Terra firme forest.

The collecting and observation methods applied in both areas (SBS, AS, DVTCS, NVTCS) revealed that the alluvial forest has a greater number of species (35 species, $70 \%$ of the total), twelve of which were recorded only in this forest type (Allobates sp. 2, Dendropsophus leucophyllatus, D. rossaleni, Hypsiboas boans, $H$. fasciatus, Osteocephalus buckleyi, Scartyla goinorum, Sphaenorhynchus dorisae, S. lacteus, Leptodactylus knudseni, Lithobates palmipes, and Pristimantis ockendeni). Totaling 31 species, the terra firme forest came second in number of species ( $62 \%$ of the total).
Regarding the total species abundance in the terra firme forest (TFF) and the alluvial forest (AF), verified using the methods AS, DVTCS, and NVTCS, 946 individuals belonging to 38 species were recorded. Table 1 contains data on absolute abundance, relative abundance, Shannon-Wiener diversity index $\left(\mathrm{H}^{\prime}\right)$, Evenness $\left(\mathrm{J}^{\prime}\right)$ and dominance (d) of the two forest types. A larger number of individuals (482 specimens) was found in the terra firme forest compared to the alluvial forest (464 specimens), but this difference between was not significant $\left(\chi^{2}=\right.$ 0.34, $\mathrm{gl}=1, \mathrm{p}=0.55$ ).

Although the terra firme forest displayed lower anuran richness, it had the highest diversity index, greater evenness and, consequently, lower dominance $\left(\mathrm{H}^{\prime}=2.12, \mathrm{~J}^{\prime}=0.67, \mathrm{~d}=\right.$ $0.38)$ when compared with the alluvial forest $\left(\mathrm{H}^{\prime}=1.69, \mathrm{~J}^{\prime}=\right.$ $0.51, \mathrm{~d}=0.62$ ).

\section{Breeding grounds and calling season}

Of the 50 species recorded, 25 were observed in breeding environments. Table 2 presents data on the distribution of anuran species in the studied habitats, their breeding environments, vertical distribution, and type of substrate used during calling activity.

Most species (13) used the abandoned meander. Twelve species were recorded in a temporary pond located on the edge of the forest. Six species were recorded in temporary ponds inside forested areas. Three species were recorded in waterlogged sites located in the forested area and only two species in the temporary igarapé.

Regarding the preference in the use of environments, Hypsiboas lanciformis was the only generalist species occupying three breeding environments. Eight species were recorded only in the abandoned meander (Dendropsophus leucophyllatus, $D$. rossaleni, $H$. boans, $H$. calcaratus, $H$. fasciatus, $H$. punctatus, Sphaenorhynchus dorisae, and S. lacteus). Four species were found only in the temporary pond at the forest edge (Rhinella marina, H. geographicus, Trachycephalus typhonius, and Leptodactylus chaquensis). Three species were found to be exclusive to temporary ponds in forested areas (Allobates sp. 1, Amazophrynella minuta, and L. rhodomystax).

In total, 32 species were observed calling (Table 3). Vocalization activity over the twelve months of collection, with greater activity in the rainy season (October to March). Aggregations associated with explosive breeding were observed in two species, Rhinella marina and Trachycephalus typhonus. Rhinella marina aggregations were observed on a single day during the night of October 2008 and aggregations of $T$. typhonius on two days during daytime and at night between December 2008 to March 2009.

Calling activity took place primarily at night. Only three species, Allobates sp. 1, Allobates sp. 2, and Amazophrynella minuta were active during the day. Rhinella margaritifera, Sphaenorhynchus dorisae, S. lacteus, and Hamptophryne boliviana, though primarily nocturnal, were recorded calling sporadically during the day. 
Table 1. Species of anurans recorded in the Lower Moa River forest from October 2008 to September 2009 and its abundance for two forest types: terra firme forest and alluvial forest. Sampling methods: (1) PFT: pitfall traps, (2) AS: active search, (3) DVTCS: diurnal visual time constrained search, (4) NVTCS: nocturnal visual time constrained search, (5) SBS: sampling at breeding sites, (6) AR: aural records.

\begin{tabular}{|c|c|c|c|c|c|}
\hline \multirow[t]{2}{*}{ Family/species } & \multirow[t]{2}{*}{ Sampling methods } & \multicolumn{2}{|c|}{ Absolute abundance } & \multicolumn{2}{|c|}{ Relative abundance } \\
\hline & & Terra firme & Alluvial & Terra firme & Alluvial \\
\hline \multicolumn{6}{|l|}{ Aromobatidae } \\
\hline Allobates sp. 1 & $1,2,3,4,6$ & 187 & & 0.388 & \\
\hline Allobates sp. 2 & $2,3,6$ & & 23 & & 0.050 \\
\hline \multicolumn{6}{|l|}{ Bufonidae } \\
\hline Amazophrynella minuta (Melin, 1941) & $1,2,3,4,6$ & 9 & & 0.019 & \\
\hline Rhaebo guttatus (Schneider, 1799) & 1 & & & & \\
\hline Rhinella castaneotica (Caldwell, 1991) & $1,2,3,4$ & 2 & 2 & 0.004 & 0.004 \\
\hline Rhinella margaritifera (Laurenti, 1768) & $1,2,3,4,5,6$ & 77 & 290 & 0.160 & 0.625 \\
\hline Rhinella marina (Linnaeus, 1758) & $1,2,5,6$ & & & & \\
\hline \multicolumn{6}{|l|}{ Craugastoridae } \\
\hline Oreobates quixensis Jiménez de la Espada, 1872 & 1,6 & & & & \\
\hline Pristimantis conspicillatus (Günther, 1858) & $1,2,3,4,6$ & 60 & 2 & 0.124 & 0.004 \\
\hline Pristimantis ockendeni (Boulenger, 1912) & 4,6 & & & & \\
\hline \multicolumn{6}{|l|}{ Hemiphractidae } \\
\hline Hemiphractus helioi Sheil \& Mendelson, 2001 & 4 & 2 & & 0.004 & \\
\hline \multicolumn{6}{|l|}{ Hylidae } \\
\hline Dendropsophus parviceps (Boulenger, 1882) & $4,5,6$ & 12 & 10 & 0.025 & 0.022 \\
\hline Dendropsophus leucophyllatus (Beireis, 1783) & 5,6 & & & & \\
\hline Dendropsophus rossalleni (Goin, 1959) & 5,6 & & & & \\
\hline Dendropsophus sarayacuensis (Shreve, 1935) & 4 & 2 & & 0.004 & \\
\hline Dendropsophus triangulum (Günther, 1869, 1868) & 5,6 & & & & \\
\hline Dendropsophus gr. microcephalus (Cope, 1886) & $4,5,6$ & 3 & & 0.006 & \\
\hline Hypsiboas boans (Linnaeus, 1758 ) & 5,6 & & & & \\
\hline Hypsiboas calcaratus (Troschel \& Schomburgk, 1848) & $4,5,6$ & & 6 & & 0.013 \\
\hline Hypsiboas cinereascens (Spix, 1824) & 5,6 & & & & \\
\hline Hypsiboas fasciatus (Günther, 1859) & 4,6 & & 3 & & 0.006 \\
\hline Hypsiboas geographicus (Spix, 1824) & $3,4,5,6$ & 4 & & 0.008 & \\
\hline Hypsiboas lanciformis (Cope, 1871) & $4,5,6$ & & 14 & & 0.030 \\
\hline Hypsiboas punctatus (Schneider, 1799) & $4,5,6$ & 6 & 9 & 0.012 & 0.019 \\
\hline Osteocephalus buckleyi (Boulenger, 1882) & 4 & & 1 & & 0.002 \\
\hline Osteocephalus leprieurii (Duméril \& Bibron, 1841) & 4,6 & 24 & 35 & 0.050 & 0.075 \\
\hline Osteocephalus taurinus Steindachner, 1862 & 3,4 & 35 & 9 & 0.073 & 0.019 \\
\hline Phyllomedusa bicolor (Boddaert, 1772) & $3,5,6$ & & 1 & & 0.002 \\
\hline Scarthyla goinorum (Bokermann, 1962) & 4 & & 2 & & 0.004 \\
\hline Scinax cruentommus (Duellman, 1972) & 4 & 14 & & 0.029 & \\
\hline Scinax funereus (Cope, 1874) & 4 & 11 & 1 & 0.023 & 0.002 \\
\hline Scinax garbei (Miranda-Ribeiro, 1926) & $2,4,5,6$ & 13 & 14 & 0.027 & 0.030 \\
\hline Scinax ruber (Laurenti, 1768) & $4,5,6$ & 5 & 6 & 0.010 & 0.013 \\
\hline Sphaenorhynchus dorisae (Goin, 1957) & $4,5,6$ & & 3 & & 0.006 \\
\hline Sphaenorhynchus lacteus (Daudin, 1800) & 5,6 & & & & \\
\hline Trachycephalus typhonius (Laurenti, 1768) & 5,6 & & & & \\
\hline
\end{tabular}


Table 1. Continued.

\begin{tabular}{|c|c|c|c|c|c|}
\hline \multirow{2}{*}{ Family/species } & \multirow{2}{*}{ Sampling methods } & \multicolumn{2}{|c|}{ Absolute abundance } & \multicolumn{2}{|c|}{ Relative abundance } \\
\hline & & Terra firme & Alluvial & Terra firme & Alluvial \\
\hline \multicolumn{6}{|l|}{ Leptodactylidae } \\
\hline Adenomera andreae Müller, 1923 & $1,2,3,4,5,6$ & 2 & 4 & 0.004 & 0.009 \\
\hline Adenomera hylaedactyla (Cope, 1868) & $1,2,3,4,5,6$ & 1 & 4 & 0.002 & 0.009 \\
\hline Leptodactylus chaquensis Cei, 1950 & 5 & & & & \\
\hline Leptodactylus knudseni (Heyer, 1972) & 4 & & 1 & & 0.002 \\
\hline Leptodactylus lineatus (Schneider, 1799) & 1,4 & & 1 & & 0.002 \\
\hline Leptodactylus mystaceus (Spix, 1824) & 1,3 & 1 & & 0.002 & \\
\hline Leptodactylus pentadactylus (Laurenti, 1768) & $4,5,6$ & & 3 & & 0.006 \\
\hline Leptodactylus petersii (Steindachner, 1864) & $1,2,3,4,5,6$ & 4 & 6 & 0.008 & 0.013 \\
\hline Leptodactylus rhodomystax Boulenger, 1884 & $1,4,5,6$ & 6 & & 0.013 & \\
\hline Chiasmocleis bassleri Dunn, 1949 & 1,4 & 1 & & 0.002 & \\
\hline Chiasmocleis hudsoni Parker, 1940 & 1,4 & 1 & & 0.002 & \\
\hline Chiasmocleis ventrimaculata (Andersson, 1945) & 1 & & & & \\
\hline Hamptophryne boliviana (Parker, 1927) & 4,6 & & 1 & & 0.002 \\
\hline \multicolumn{6}{|l|}{ Ranidae } \\
\hline Lithobates palmipes (Spix, 1824) & 3,4 & & 2 & & 0.004 \\
\hline \multicolumn{6}{|l|}{ Total: 50 species } \\
\hline Total of specimes $(\mathrm{N})$ & & 482 & 464 & & \\
\hline Shannon-Wiener diversity index $\left(\mathrm{H}^{\prime}\right)$ & & 2.12 & 1.69 & & \\
\hline Evenness $\left(J^{\prime}\right)$ & & 0.67 & 0.51 & & \\
\hline Dominance of Berger-Parker (d) & & 0.38 & 0.62 & & \\
\hline
\end{tabular}

Thirty species were found calling during the rainy season, and 28 species in the dry season. The calling activity of five species was restricted to the rainy season, with the end of the activity occurring before the onset of the dry season or in the early dry season (Amazophrynella minuta, Dendropsophus parviceps, D. gr. microcephalus, Hypsiboas cinereascens, and Leptodactylus rhodomystax). Table 3 also shows anuran calling activity and abundance of anurans recorded by month. A smaller number of individuals were found in the rainy season. Although most species were recorded vocalizing during the rainy season, from October to March, no significant correlation was found between the number of species in calling activity and monthly rainfall ( $r s=0.3286, p=0.2969, t=1.1004)$, nor between the number of species in calling activity and monthly temperature ( $\mathrm{rs}=0.3020$, $\mathrm{p}=0.3401, \mathrm{t}=1.0016$ ).

When a dry season started in April we observed a greater number of specimens, lower diversity index and lower evenness and higher dominance $\left(\mathrm{H}^{\prime}=2.29, \mathrm{~J}^{\prime}=0.63\right.$ and $\left.\mathrm{d}=0.38\right)$. This happened even though the alluvial forest was still completely flooded as a result of high amounts rainfall in March. In the rainy season the diversity index was higher, evenness was greater and dominance was lower $\left(\mathrm{H}^{\prime}=2.70, \mathrm{~J}^{\prime}=0.75\right.$ and $\mathrm{d}=0.29$ ). There was a significant difference in the number of individuals recorded between periods $\left(\chi^{2}=6.6, \mathrm{gl}=1, \mathrm{p}=0.009\right)$, but these were not correlated with monthly rainfall (rs = $-0.4939, \mathrm{p}=0.1026, \mathrm{t}=-1.7961)$ and temperature ( $\mathrm{rs}=-0.1532$, $\mathrm{p}=0.6346, \mathrm{t}=-0.4901)$ data.

\section{Use of environmental resources and breeding sites}

The anurans of the Lower Moa River forest were found in more numbers in the leaf litter (23 species), followed by woody vegetation (21), shrub (18), palm (15), herbaceous vegetation (16), seedlings (9), vines (7), fallen branches and logs (7), aquatic vegetation (7), grasses (4) and ground without the presence of leaf litter (4).

Hylidae was the best represented in the substrates (Fig. 5). It was recorded in all substrates in very high percentages, except on the ground devoid of leaf litter. Only one individual of Osteocephalus taurinus was found in soil with leaf litter. Bufonidae was present in nine of the eleven substrates, with individuals of Rhinella margaritifera occupying most types of substrates. All other species of this family where found on the ground covered with leaf litter, except for individuals of Amazophrynella minuta, wich were found resting on seedlings during the night. 
Table 2. Habitats, breeding environments, vertical distribution and type of substrate used by the species of anurans of the Lower Moa River. Habitats: (TFF) Terra firme forest, (AF) Alluvial forest, (FE) Forest edge. Breeding environments: (TI) temporary igarapé, (AM) abandoned meander, (TPF) temporary ponds in forested environment, (TPE) temporary ponds on the forest edge, (WE) waterlogged environment. Vertical distribution: (t) terrestrial, (a) arboreal. Substrates: (GO) ground without the presence of leaf litter, (GR) grasses, (LL) leaf litter, (WV) woody vegetation, (SB) shrubs, (HV) herbaceous vegetation, (VI) vines, (PA) palms, (BL) fallen branches and logs, (SE) seedlings, (AV) aquatic vegetation. ( $\left.{ }^{*}\right)$ Substrate used by the species of anurans during calling activity.

\begin{tabular}{|c|c|c|c|c|c|c|}
\hline Family/species & & Habitats & & Breeding environments & Vertical distribution & Substrate \\
\hline \multicolumn{7}{|l|}{ Aromobatidae } \\
\hline Allobates sp. 1 & TFF & & & TPF & $\mathrm{t}$ & *LL, SE \\
\hline Allobates sp. 2 & & $\mathrm{AF}$ & & & $\mathrm{t}$ & ${ }^{*} \mathrm{LL}$ \\
\hline \multicolumn{7}{|l|}{ Bufonidae } \\
\hline A. minuta & TFF & & & TPF & $\mathrm{t}$ & *LL, SE \\
\hline R. guttatus & TFF & & & - & $\mathrm{t}$ & LL \\
\hline R. castaneotica & TFF & $\mathrm{AF}$ & & - & $\mathrm{t}$ & LL \\
\hline R. margaritifera & TFF & $\mathrm{AF}$ & $\mathrm{FE}$ & TPF, TI & $t / a$ & LL, WV, SB, HV, VI, PA, BL, SE \\
\hline R. marina & TFF & $\mathrm{AF}$ & $\mathrm{FE}$ & TPE & & GO, LL \\
\hline \multicolumn{7}{|l|}{ Craugastoridae } \\
\hline O. quixensis & TFF & & & - & $\mathrm{t}$ & $\mathrm{LL}$ \\
\hline P. conspicillatus & TFF & $\mathrm{AF}$ & & - & $a / t$ & LL, WV, SB, HV, PA, SE \\
\hline P. ockendeni & & $\mathrm{AF}$ & & - & a & $W V, S B, P A$ \\
\hline \multicolumn{7}{|l|}{ Hemiphractidae } \\
\hline H. helioi & TFF & & & - & a & SB, SE \\
\hline \multicolumn{7}{|l|}{ Hylidae } \\
\hline D. parviceps & TFF & $\mathrm{AF}$ & & TPF, WE & a & $W V, S B, H V, P A, B L$ \\
\hline D. leucophyllatus & & $\mathrm{AF}$ & & AM & a & *AV \\
\hline D. rossaleni & & $\mathrm{AF}$ & & AM & a & $W V, S B, A V$ \\
\hline D. sarayacuensis & TFF & & & - & a & WV, HV \\
\hline D. gr. microcephalus & TFF & & $\mathrm{FE}$ & TPE, TI & a & $G R, W V, H V$ \\
\hline D. triangulum & & $\mathrm{AF}$ & $\mathrm{FE}$ & AM, TPE & a & ${ }^{*} \mathrm{GR},{ }^{*} \mathrm{AV}$ \\
\hline H. boans & & $\mathrm{AF}$ & & AM & a & $\mathrm{VI}$ \\
\hline H. calcaratus & TFF & $\mathrm{AF}$ & & AM & a & $\mathrm{WV}, \mathrm{SB}, \mathrm{HV}$ \\
\hline H. cinereascens & & $\mathrm{AF}$ & $\mathrm{FE}$ & AM, TPE & a & ${ }^{*} \mathrm{GR},{ }^{*} \mathrm{AV}$ \\
\hline H. fasciatus & & $\mathrm{AF}$ & & AM & a & $W V, S B, P A$ \\
\hline H. geographicus & TFF & & $\mathrm{FE}$ & TPE & a & $\mathrm{WV}, \mathrm{SB}$ \\
\hline H. lanciformis & & $\mathrm{AF}$ & $\mathrm{FE}$ & AM, TPE, WE & a & $\mathrm{WV}, \mathrm{SB}, \mathrm{HV}, \mathrm{PA}, \mathrm{BL}, \mathrm{SE}$ \\
\hline H. punctatus & TFF & $\mathrm{AF}$ & & AM & a & $\mathrm{WV}, \mathrm{SB}, \mathrm{HV}, \mathrm{VI}, \mathrm{PA}, \mathrm{SE}$ \\
\hline O. buckleyi & & $\mathrm{AF}$ & & - & a & PA \\
\hline O. leprieuri & TFF & $\mathrm{AF}$ & & - & a & $\mathrm{WV}, \mathrm{SB}, \mathrm{HV}, \mathrm{VI}, \mathrm{PA}, \mathrm{BL}$ \\
\hline O. taurinus & TFF & $\mathrm{AF}$ & & - & a & LL, WV, SB, HV, VI, PA, BL, SE \\
\hline P. bicolor & TFF & $\mathrm{AF}$ & & TPF, TPE & a & $\mathrm{WV}, \mathrm{HV}$ \\
\hline S. goinorum & & $\mathrm{AF}$ & & - & a & $\mathrm{SB}, \mathrm{HV}$ \\
\hline S. cruentomus & TFF & & & - & a & $\mathrm{WV}, \mathrm{SB}, \mathrm{HV}, \mathrm{VI}, \mathrm{PA}, \mathrm{BL}$ \\
\hline S. funereus & TFF & $\mathrm{AF}$ & & - & a & $\mathrm{WV}, \mathrm{SB}, \mathrm{HV}, \mathrm{VI}, \mathrm{PA}$ \\
\hline S. garbei & TFF & $\mathrm{AF}$ & $\mathrm{FE}$ & AM, TPE & a & WV, SB, HV, PA, BL, SE \\
\hline S. ruber & TFF & $\mathrm{AF}$ & $\mathrm{FE}$ & TPE, WE & a & $W V, S B, H V, P A$ \\
\hline S. dorisae & & $\mathrm{AF}$ & & $\mathrm{AM}$ & a & $\mathrm{WV}, \mathrm{PA},{ }^{*} \mathrm{AV}$ \\
\hline S. lacteus & & $\mathrm{AF}$ & & AM & $\mathrm{a}$ & *AV \\
\hline T. typhonius & & $\mathrm{AF}$ & $\mathrm{FE}$ & TPE & $\mathrm{a}$ & ${ }^{\star} \mathrm{GR}, \mathrm{WV}$ \\
\hline
\end{tabular}


Table 2. Continued.

\begin{tabular}{|c|c|c|c|c|c|c|}
\hline Family/species & & Habitats & & Breeding environments & Vertical distribution & Substrate \\
\hline \multicolumn{7}{|l|}{ Leptodactylidae } \\
\hline A. andreae & TFF & $\mathrm{AF}$ & $\mathrm{FE}$ & - & $\mathrm{t}$ & ${ }^{*} \mathrm{GO},{ }^{*} \mathrm{LL}$ \\
\hline A. hylaedactyla & TFF & $\mathrm{AF}$ & $\mathrm{FE}$ & - & $\mathrm{t}$ & ${ }^{*} \mathrm{GO},{ }^{*} \mathrm{LL}$ \\
\hline L. chaquensis & & & $\mathrm{FE}$ & TPE & $\mathrm{t}$ & GO \\
\hline L. lineatus & TFF & $\mathrm{AF}$ & & - & $\mathrm{t}$ & LL \\
\hline L. mystaceus & TFF & & & - & $\mathrm{t}$ & LL \\
\hline L. pentadactylus & TFF & $\mathrm{AF}$ & & - & $\mathrm{t}$ & LL \\
\hline L. knudseni & & $\mathrm{AF}$ & & - & $\mathrm{t}$ & $\mathrm{LL}$ \\
\hline L. petersii & TFF & $\mathrm{AF}$ & $\mathrm{FE}$ & AM, TPE & $\mathrm{t}$ & $\mathrm{LL}, \mathrm{AV}$ \\
\hline L. rhodomystax & TFF & & & TPF & $\mathrm{t}$ & LL \\
\hline \multicolumn{7}{|l|}{ Microhylidae } \\
\hline C. bassleri & TFF & & & - & $\mathrm{t}$ & LL \\
\hline C. hudsoni & TFF & & & - & $\mathrm{t}$ & LL \\
\hline C. ventrimaculata & TFF & & & - & $\mathrm{t}$ & LL \\
\hline H. boliviana & TFF & $\mathrm{AF}$ & & - & $\mathrm{t}$ & LL \\
\hline \multicolumn{7}{|l|}{ Ranidae } \\
\hline L. palmipes & & $\mathrm{AF}$ & & - & $\mathrm{t}$ & $\mathrm{LL}$ \\
\hline Total & 33 & 35 & 15 & & & \\
\hline
\end{tabular}

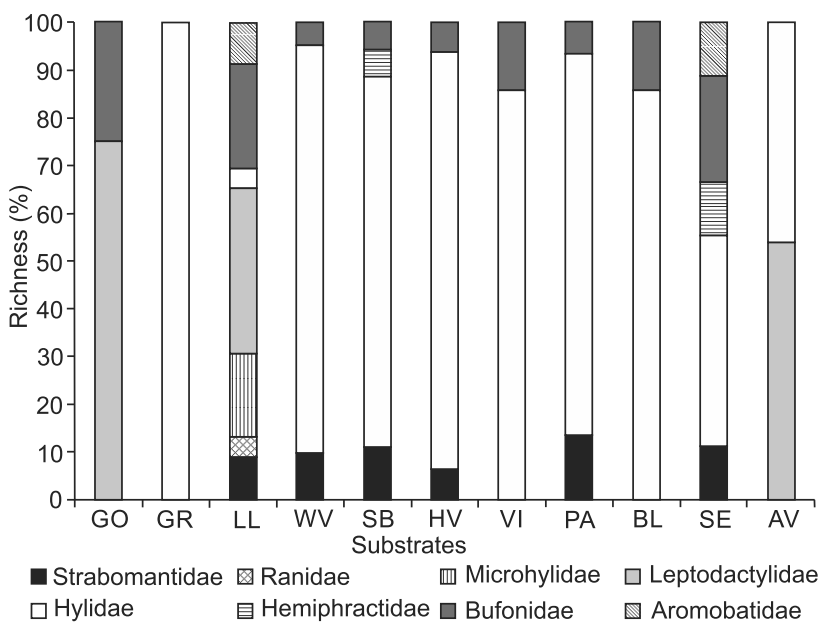

Figure 5. Percentage of richness of anurans by family. Substrates: (GO) ground without the presence of leaf litter, (GR) grasses, (LL) leaf litter, (WV) woody vegetation, (SB) shrubs, (HV) herbaceous vegetation, $(\mathrm{VI})$ vines, $(\mathrm{PA})$ palms, $(\mathrm{BL})$ fallen branches and logs, $(\mathrm{SE})$ seedlings, $(\mathrm{AV})$ aquatic vegetation.

Adult individuals of the other families were found mostly in leaf litter and seedlings. In the latter, juveniles of four species were also found: Rhinella margaritifera, Hypsiboas punctatus, Osteocephalus taurinus, and Scinax garbei.

Regarding the breeding sites, some species showed some degree of fidelity to the calling site. For example, species of Allobates and Amazophrynella minuta commonly called from the leaf litter, Adenomera andreae and A. hylaedactyla from the leaf litter and the ground, and individuals of Sphaenorhynchus and Dendropsophus triangulum from floating aquatic vegetation. The latter species was also found vocalizing on grass.

Table 4 displays the frequency of substrate use by the most abundant frog species $(n>10)$ recorded by the DVTCS, NVTCS and AS methods. Species that were visualized in small numbers on a certain subtract $s(n<10)$ were not included in this table.

Four species were host specific: two from Aromobatidae (Allobates sp. 1 and Allobates sp. 2) and one from Bufonidae (Amazophrynella minuta). During the day they were found more frequently dwelling and calling from the ground covered by leaf litter. At night these species were found resting on short seedlings o $(5 \mathrm{~cm}$ to $30 \mathrm{~cm})$. Leptodactylus petersii was found more frequently on the forest floor. One record of it was on floating aquatic vegetation in April 2009, when the alluvial forest was flooded.

Most species failed to show a preference for a given substrate. Nine species were found on more than five substrates. Rhinella margaritifera and Osteocephalus taurinus were the most generalist species. Both were recorded in eight types of substrate.

The species of Hylidae overlapped in their vertical distribution (Table 5). Most species were found in substrates ranging from 10 to $120 \mathrm{~cm}$ high. Osteocephalus taurinus and $O$. leprieurii overlapped in their use of substrates and height. They 
Table 3. Anurans calling activity and abundance of anurans recorded in the Lower Moa River forest from October 2008 to September 2009. (CAP) Calling activity period, (n) nocturnal, (d) diurnal, (de) diurnal sporadically, (?) specie recorded in calling activity, (?) specie recorded but without calling activity, (?s) specie recorded in calling activity sporadically, (T) total.

\begin{tabular}{|c|c|c|c|c|c|c|c|c|c|c|c|c|c|c|c|}
\hline \multirow{3}{*}{ Species } & \multirow{3}{*}{ CAP } & \multicolumn{14}{|c|}{ Months of sampling } \\
\hline & & \multicolumn{7}{|c|}{2008} & \multicolumn{7}{|c|}{2009} \\
\hline & & Oct & Nov & Dec & Jan & Feb & Mar & $\mathrm{T}$ & Apr & May & Jun & Jul & Aug & Sep & $\mathrm{T}$ \\
\hline Allobates sp. 1 & $d$ & $\bullet 23$ & $\bullet 28$ & $\bullet 6$ & $\bullet 12$ & $\bullet 8$ & $\bullet 6$ & 83 & $\bullet$ & 017 & O43 & $\mathrm{O} 32$ & $\bullet$-537 & $\bullet 18$ & 158 \\
\hline Allobates sp. 2 & $d$ & $\bullet 3$ & $\bullet 3$ & $\bullet$ & $\bullet 2$ & $\bullet 1$ & $\bullet 5$ & 14 & - & 01 & $\bigcirc 4$ & $\mathrm{O} 2$ & $\bullet$ & $\bullet 2$ & 9 \\
\hline A. minuta & $d$ & 01 & 01 & ○4 & $\mathrm{O} 2$ & $\bullet$ & $\bullet 1$ & 9 & $\bullet$ & O7 & 012 & $\mathrm{O} 2$ & O7 & - & 28 \\
\hline R. guttatus & & $\mathrm{O} 2$ & - & 01 & - & $\mathrm{O} 3$ & - & 6 & 01 & - & - & - & - & - & 1 \\
\hline R. castaneotica & & 01 & - & - & 01 & - & - & 2 & - & 01 & $\mathrm{O} 2$ & $\mathrm{O} 2$ & - & 01 & 6 \\
\hline R. margaritifera & $\mathrm{n} / \mathrm{de}$ & •s14 & $\bullet 9$ & $\bullet 46$ & $\bullet 30$ & $\bullet 28$ & $\bullet 44$ & 171 & $\bullet 31$ & 065 & $\bullet 44$ & $\bullet 44$ & O42 & O30 & 256 \\
\hline R. marina & $\mathrm{n}$ & $\bullet 1$ & 01 & 01 & 01 & - & - & 4 & O & O & - & $\mathrm{O} 2$ & O & - & 2 \\
\hline O. quixensis & $\mathrm{n}$ & - & 01 & - & - & - & - & 1 & - & - & - & •s & - & -s & 0 \\
\hline P. conspicillatus & $\mathrm{n}$ & 01 & $\mathrm{O} 2$ & $\mathrm{O} 2$ & - & O6 & O6 & 17 & $\mathrm{O} 21$ & 012 & 07 & O5 & $\bullet 1$ & $\mathrm{O} 2$ & 48 \\
\hline P. ockendeni & $\mathrm{n}$ & $\bullet 3$ & $\bullet$ & $\bullet 2$ & $\bullet$ & - & - & 5 & - & 01 & $\bullet 2$ & $\bullet 1$ & $\bullet 1$ & $\bullet 1$ & 6 \\
\hline H. helioi & & - & 01 & 01 & - & - & - & 2 & - & - & - & - & - & - & 0 \\
\hline D. leucophyllatus & $\mathrm{n}$ & $\bullet$ & - & $\bullet$ & $\bullet$ & $\bullet$ & $\bullet$ & 0 & - & - & - & - & $\bullet$ & $\bullet$ & 0 \\
\hline D. parviceps & $\mathrm{n}$ & $\mathrm{O} 2$ & - & 01 & $\bullet$ & $\bullet$ & $\bullet 3$ & 6 & $\bullet$ & $\mathrm{O} 2$ & $\mathrm{O} 3$ & O3 & O3 & O5 & 16 \\
\hline D. rossaleni & $\mathrm{n}$ & $\bullet$ & $\bullet$ & $\bullet$ & $\bullet$ & $\bullet$ & $\bullet$ & 0 & - & - & $\bullet$ & $\bullet$ & $\bullet$ & $\bullet$ & 0 \\
\hline D. sarayacuensis & & - & 01 & - & - & - & - & 1 & - & - & - & - & 01 & - & 1 \\
\hline D. triangulum & $\mathrm{n}$ & $\bullet$ & $\bullet$ & $\bullet$ & $\bullet$ & $\bullet$ & $\bullet$ & 0 & $\bullet$ & $\bullet$ & $\bullet$ & $\bullet$ & $\bullet$ & $\bullet$ & 0 \\
\hline D.gr.microcephalus & $\mathrm{n}$ & $\bullet 1$ & $\bullet$ & - & $\bullet$ & - & $\bullet$ & 1 & $\bullet$ & - & - & $\mathrm{O} 2$ & - & - & 2 \\
\hline H. boans & $\mathrm{n}$ & $\bullet$ & $\bullet$ & - & $\bullet$ & $\bullet$ & - & 0 & - & - & $\bullet$ & $\bullet$ & $\bullet$ & $\bullet$ & 0 \\
\hline H. calcaratus & $\mathrm{n}$ & $\bullet 1$ & $\bullet 1$ & $\bullet 3$ & $\bullet$ & $\bullet$ & $\bullet$ & 5 & $\bullet 1$ & $\bullet$ & $\bullet$ & $\bullet$ & 01 & $\bullet 1$ & 3 \\
\hline H. cinereascens & $\mathrm{n}$ & $\bullet$ & $\bullet$ & $\bullet$ & $\bullet$ & $\bullet$ & $\bullet$ & 0 & $\bullet$ & - & - & - & - & - & 0 \\
\hline H. fasciatus & $\mathrm{n}$ & $\bullet$ & - & $\bullet 1$ & - & $\bullet 1$ & - & 2 & - & - & - & - & - & 01 & 1 \\
\hline H. geographicus & $\mathrm{n}$ & - & $\bullet$ & - & - & - & - & 0 & - & - & 01 & 01 & 01 & 01 & 4 \\
\hline H. lanciformis & $\mathrm{n}$ & $\bullet$ & $\bullet$ & $\bullet 10$ & $\bullet 1$ & $\bullet 1$ & $\bullet$ & 12 & $\bullet 1$ & $\bullet 1$ & $\bullet$ & $\bullet$ & $\bullet$ & $\bullet$ & 2 \\
\hline H. punctatus & $\mathrm{n}$ & $\bullet$ & $\bullet$ & $\bullet$ & $\bullet$ & $\bullet$ & $\bullet 2$ & 2 & $\bullet 1$ & $\bullet$ & $\bullet 2$ & $\bullet 2$ & $\bullet 7$ & $\bullet 1$ & 13 \\
\hline O. buckleyi & & - & - & - & - & - & - & 0 & 01 & - & - & - & - & - & 1 \\
\hline O. leprieurii & & 010 & 07 & O5 & $\bigcirc 4$ & O5 & ○4 & 35 & 01 & ○4 & $\bigcirc 4$ & ○4 & $\bigcirc 4$ & 07 & 24 \\
\hline O. taurinus & & 07 & 012 & O1 & 01 & O7 & - & 28 & 01 & - & $\mathrm{O} 2$ & O4 & 01 & O3 & 11 \\
\hline P. bicolor & $\mathrm{n}$ & $\bullet$ & $\bullet$ & $\bullet$ & $\bullet$ & - & $\bullet$ & 0 & - & $\bullet$ & $\bullet 1$ & $\bullet$ & $\bullet$ & $\bullet$ & 1 \\
\hline S. goinorum & & - & - & - & - & 01 & - & 1 & - & - & - & - & - & 01 & 1 \\
\hline S. cruentommus & & 01 & - & O1 & - & $\mathrm{O} 3$ & 01 & 6 & - & - & $\mathrm{O} 3$ & 01 & 01 & O3 & 8 \\
\hline S. funereus & & 01 & O & 01 & $\mathrm{O} 2$ & $\mathrm{O} 3$ & 01 & 8 & 01 & - & - & - & $\mathrm{O} 2$ & 01 & 4 \\
\hline S. garbei & $\mathrm{n}$ & $\bullet 3$ & $\bullet 2$ & $\bullet 5$ & $\bullet$ & $\bullet 2$ & $\bullet 3$ & 15 & O6 & $\mathrm{O} 2$ & O & 01 & $\mathrm{O} 3$ & - & 12 \\
\hline S. ruber & $\mathrm{n}$ & $\bullet$ & $\bullet 7$ & $\bullet$ & $\bullet$ & $\bullet 1$ & $\bullet$ & 8 & - & $\bullet 1$ & - & 01 & 01 & - & 3 \\
\hline S. dorisae & $\mathrm{n} / \mathrm{de}$ & $\bullet$ & $\bullet 1$ & $\bullet$ & $\bullet$ & $\bullet$ & $\bullet$ & 1 & $\bullet$ & $\bullet$ & $\bullet$ & $\bullet$ & $\bullet 1$ & $\bullet 1$ & 2 \\
\hline S. lacteus & $\mathrm{n} / \mathrm{de}$ & $\bullet$ & $\bullet$ & $\bullet$ & $\bullet$ & $\bullet$ & $\bullet$ & 0 & $\bullet$ & $\bullet$ & $\bullet$ & $\bullet$ & $\bullet$ & $\bullet$ & 0 \\
\hline T. typhonius & $\mathrm{n} / \mathrm{d}$ & - & - & $\bullet$ & O & - & $\bullet$ & 0 & - & - & - & - & $\bullet^{s}$ & $\bullet$ & 0 \\
\hline A. andreae & $n$ & $\bullet$ & $\bullet$ & $\bullet$ & $\bullet$ & $\bullet$ & $\bullet 1$ & 1 & $\mathrm{O} 2$ & $\mathrm{O} 2$ & - & $\bullet 1$ & $\bullet 1$ & $\bullet 2$ & 8 \\
\hline A. hylaedactyla & $\mathrm{n}$ & $\bullet$ & $\bullet$ & - & $\bullet$ & $\bullet$ & $\bullet$ & 0 & - & 01 & $\bullet$ & $\bullet$ & $\bullet 2$ & $\bullet 2$ & 5 \\
\hline L. chaquensis & & O & O & O & O & O & O & 0 & O & O & O & $\circ$ & O & O & 0 \\
\hline L. knudseni & & - & - & - & - & - & - & 0 & - & 01 & - & - & - & - & 1 \\
\hline L. lineatus & & O2 & 01 & $\circ 2$ & - & 01 & - & 6 & 01 & 01 & - & 01 & 01 & - & 4 \\
\hline L. mystaceus & & ०6 & O3 & 05 & $\mathrm{O} 2$ & 01 & O3 & 20 & ○2 & - & - & 01 & - & $\mathrm{O} 2$ & 5 \\
\hline
\end{tabular}


Table 3. Continued.

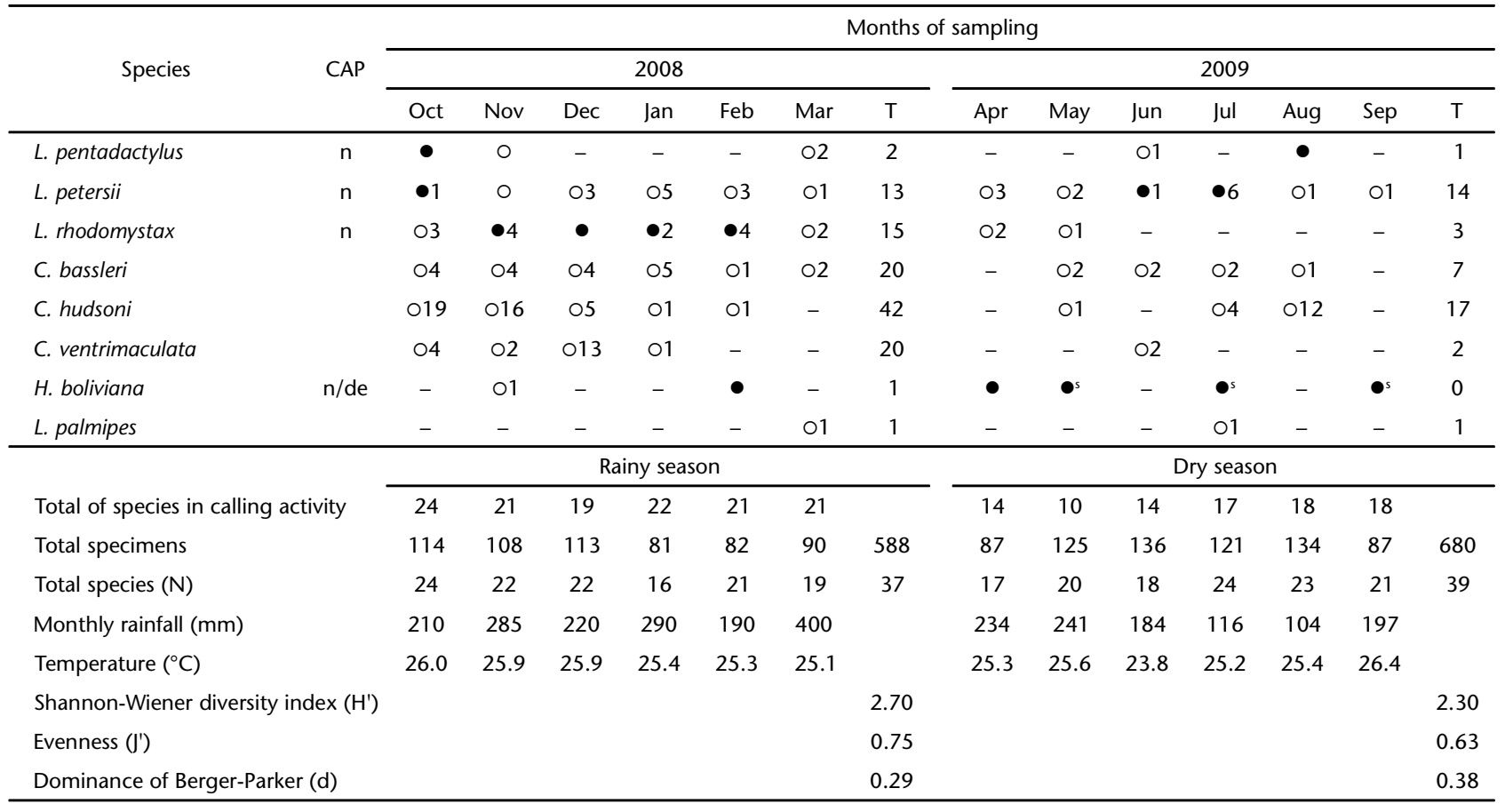

Table 4. Frequency (\%) of substrate use by the most abundant anurans species ( $n>10)$. Substrates: (LL) leaf litter, (WV) woody vegetation, $(\mathrm{SB})$ shrubs, (HV) herbaceous vegetation, (VI) vines, (PA) palms, (BL) fallen branches and logs, (SE) seedlings, (AV) aquatic vegetation. Habitats: (TFF) Terra firme forest, (AF) Alluvial forest.

\begin{tabular}{|c|c|c|c|c|c|c|c|c|c|c|c|c|}
\hline \multirow[t]{2}{*}{ Species } & \multicolumn{9}{|c|}{ Substrates } & \multicolumn{2}{|c|}{ Habitats } & \multirow[t]{2}{*}{ Total } \\
\hline & LL & wV & SB & HV & VI & PA & $\mathrm{BL}$ & SE & $\mathrm{AV}$ & TFF & $\mathrm{AF}$ & \\
\hline Allobates sp. 1 & 99.5 & & & & & & & 0.5 & & 100.0 & & 187 \\
\hline Allobates sp. 2 & 100.0 & & & & & & & & & & 100.0 & 23 \\
\hline A. minuta & 84.4 & & & & & & & 15.6 & & 100.0 & & 32 \\
\hline R. margaritifera & 75.0 & 2.6 & 5.5 & 5.5 & 0.6 & 4.9 & 1.1 & 4.9 & & 21.0 & 78.1 & 347 \\
\hline P. conspicillatus & 22.6 & 4.8 & 9.7 & 40.3 & & 6.5 & & 16.1 & & 96.8 & 3.2 & 62 \\
\hline P.ockendeni & & 25.0 & 25.0 & & 12.5 & 37.5 & & & & & 100.0 & 8 \\
\hline D. parviceps & & 33.3 & 42.8 & 14.3 & & 4.8 & 4.8 & & & 52.4 & 47.6 & 21 \\
\hline H. punctatus & & 26.7 & 13.3 & 20.0 & 13.3 & 20.0 & & 6.7 & & 400.0 & 60.0 & 15 \\
\hline O. leprieurii & & 48.0 & 26.0 & 8.0 & 2.0 & 6.0 & 10.0 & & & 38.0 & 62.0 & 50 \\
\hline O. taurinus & 3.0 & 63.6 & 9.1 & 3.0 & 3.0 & 6.1 & 9.1 & 3.0 & & 879 & 12.1 & 33 \\
\hline S. cruentommus & & 15.4 & 30.7 & 23.1 & 7.7 & 15.4 & 7.7 & & & 100.0 & & 13 \\
\hline S. funereus & & 41.7 & 33.3 & 8.3 & 8.3 & 8.3 & & & & 91.7 & 8.3 & 13 \\
\hline S. garbei & & 9.5 & 28.6 & 33.3 & & 4.8 & 9.5 & & & 52.4 & 47.6 & 21 \\
\hline L. petersii & 90.0 & & & & & & & & 10.0 & 40.0 & 60.0 & 10 \\
\hline
\end{tabular}

were recorded on trees, shrubs, herbs, vines, palm trees and fallen branches at heights ranging from $10 \mathrm{~cm}$ to over $350 \mathrm{~cm}$. Species of Scinax were also found in the same height range, but were more common between $30 \mathrm{~cm}$ to $180 \mathrm{~cm}$.

\section{Reproductive evidence}

We observed some reproductive evidence in 20 of the 50 species of anurans found in the Lower Moa River forest (Table 6). Ovulating females were encountered more often during the 
Table 5. Vertical distribution of anurans in the Lower Moa River forest (AC).

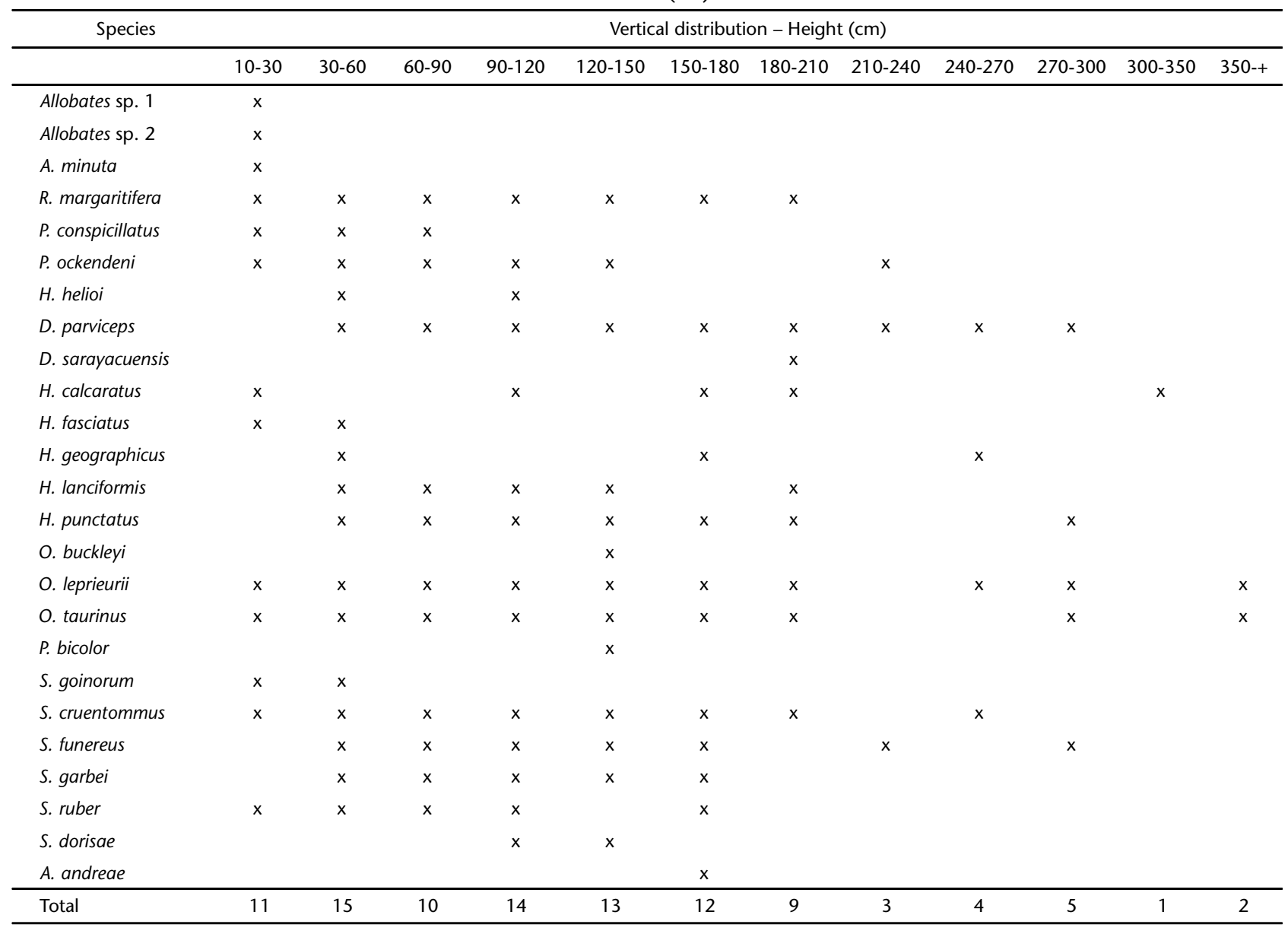

rainy season and juveniles during the dry season. Evidence of reproduction was found in 36 species (72\%) during the rainy season.

Of the species with nocturnal activity, Chiasmocleis hudsoni stands out since 23 ovulating females were captured in pitfall traps, ten in October, ten in November and three in December. Only one ovulating female of the other microhylids was found in these months. Evidence of reproduction was found in Rhinella margaritifera in all months Amplexus was observed in November and December 2008 and juveniles were present in almost every month, except November.

Juveniles of the diurnal species, Allobates sp. 1 and Amazophrynella minuta, were more abundant and were easier to encounter. Three individuals of Allobates sp. 1 were found carrying tadpoles on their backs in November, juveniles were found from January 2009 until August 2009, with a greater abundance in the months when rainfall was lower. Juveniles of Amazophrynella minuta were also found in greater numbers during months with less rainfall: May 2008 to August 2008.

\section{DISCUSSION}

\section{Richness and diversity}

Considering the size of the sampled area (256 ha), the forest of the Lower Moa River is rich in anuran species, with 50 species distributed in two main forest types: open terra firme forest with palm trees and dense alluvial forest with emergent trees. Sites in the western Brazilian Amazon seem to have a greater diversity of amphibians than those in eastern Amazon (Azevedo-Ramos \& Galattr 2002). Compared to other locations, the same number of species was found in the Adolph Ducke Reserve in Amazonia, in which the sampled area corresponds to $64 \mathrm{~km}^{2}$ or 6,400 ha (LimA et al. 2006).

Inventories of anurans in the Alto Juruá region in Acre, carried out in the Extractive Reserve Riozinho da Liberdade (size of the sampled area: $200 \mathrm{ha}$ ), recorded 80 species (BERNARDE et al. 2011). In the Serra do Divisor National Park $(843,000$ ha), 124 species were recorded in an area of approximately 3,000 ha and, in the Alto Juruá Extractive Reserve (506,000 ha), 112 
Table 6. Evidence reproductive of 20 species in the Lower Moa River forest (AC) during October 2008 to September 2009. (T) Tadpoles, (J) juveniles, (F) ovulating female, (A) amplexus, (I) imagoes.

\begin{tabular}{|c|c|c|c|c|c|c|c|c|c|c|c|c|}
\hline Species & Oct & Nov & Dec & Jan & Feb & Mar & Apr & May & Jun & Jul & Aug & Sep \\
\hline Allobates sp.1 & & $T$ & & $J$ & $J$ & & J & $J$ & J & 1 & $J$ & \\
\hline Allobates sp. 2 & & & & & & $J$ & & & & J & & \\
\hline A. minuta & & & & & & & & J & J & J & J & \\
\hline R. castaneotica & J & & & & & & & & J & & & \\
\hline R. margaritifera & $J$ & A & A J & $J$ & $J$ & J & J & J & J & J & $J$ & $J$ \\
\hline P. conspicillatus & & & $J$ & & $J$ & & & & & & & \\
\hline D. parviceps & & & & & & A & & & $\mathrm{F}$ & & & \\
\hline H. geographicus & & & & & & & & & & J & & \\
\hline H. lanciformis & & & & & I & I & & I & & & & \\
\hline H. punctatus & & & & $\mathrm{F}$ & & J & & & & & & \\
\hline O. leprieurii & & $\mathrm{F}$ & & & & & & J & J & & & \\
\hline O. taurinus & & $\mathrm{F}$ & & & J & & & & & & & \\
\hline S. cruentommus & & & & & $J$ & & & & & & & \\
\hline S. funereus & & & & $\mathrm{F}$ & $\mathrm{F}$ & & & & & & & \\
\hline S. garbei & $\mathrm{F}$ & & & & & & J & & & & & \\
\hline L. petersii & & & & & & & $\mathrm{F}$ & J & J & J & & \\
\hline L. rhodomystax & & & & $J$ & J & & & J & & & & \\
\hline C. bassleri & & $\mathrm{F}$ & & & $J$ & & & & & & & \\
\hline C. hudsoni & $\mathrm{F}$ & $\mathrm{F}$ & $\mathrm{F}$ & & J & & & & & & & \\
\hline C. ventrimaculata & $\mathrm{F}$ & $\mathrm{F}$ & & & & & & & & & & \\
\hline
\end{tabular}

species were sampled in an area of about 2,500 ha (SouzA 2009). The Alto Juruá region is also very rich in butterflies, fishes and birds (BRown \& Freitas 2002), and is considered a priority area for biodiversity conservation in the Brazilian Amazon (CAPobianco 2001).

In the Amazon, areas of terra firme are less difficult to access than the alluvial forest. Consequently, there has been more research on anurans of terra firme. Although in this study the alluvial forest has been inventoried without pitfall traps, the fact that some species were recorded only in it increases our confidence that this forest typology is rich. We believe that if pitfall traps could be used in the alluvial forest a few more species might have been found. Pitfall traps captured the greatest number of species in the terra firme forest. The fact that the alluvial forest is seasonally flooded may have influenced the Shannon-Wiener index, evenness and Berger-Parker dominance of species. Others factors, such as predation behavior or reproductive habitats, may also have influenced the activity and richness of frogs in both areas.

The alluvial forest is a more heterogeneous environment, offering a greater variety of sites where anurans can reproduce, including permanent environments (lakes) and temporary environments consisting of temporary ponds and waterlogged areas during early flooding. Spatial heterogeneity, which determines the diversity of calling sites, has been identified as an important factor determining the number of anuran species at a given environment (CARDoso et al. 1989). Studies in different biomes in Brazil (e.g., Cardoso et al. 1989, Bernarde \& KoKubum 1999, ARZABE 1999) suggest that environmental heterogeneity is associated with a greater number of species, but few studies have tested this relationship (GASCON 1991, SANTOS et al. 2007, Vasconcelos \& Rossa-Feres 2005). Environmental disturbances may also influence the structure of a community (CoNNELL 1978). A floodplain is an environment that oscillates between terrestrial and aquatic phases, and where floods are considered periods of disturbance to the terrestrial environment (JUNK 1997). Disturbance produces different habitats (ConNell 1978). Thus, the intermediate disturbance hypothesis (ConNelL 1978) can be applied to the richness of the alluvial forest. Under this hypothesis, the frequency of the disturbance is neither too intense nor too rare, thus resulting in high diversity patterns. Thus, environmental heterogeneity and the intermediate disturbance theory are two explanations that can be used to help understand the greater richness in the alluvial forest.

Another aspect that may have influenced species richness and diversity index $\left(\mathrm{H}^{\prime}\right)$ is the taxonomy of some species. The Rhinella margaritifera complex is considered problematic in taxonomic terms, with an undefined number of species that remain to be described or names that need to be revalidated (Caramaschi \& Niemeyer 2003). The high relative abundance of Rhinella margaritifera (0.625) in the alluvial forest influenced the low Shannon diversity - Wiener index in this area. Currently the Rhinella margaritifera species group consists of 16 recognized species (LaviLla et al. 2013). Changes in the iden- 
tity of the species could change the values of Shannon diversity - Wiener index in the alluvial forest. Moreover, the number of described species of Allobates (Aromobati-dae) in the Amazon has increased in recent years (KaEFer et al. 2012). Species in this genus complex are difficult to identify because the adults are morphologically similar. Unequivocal identification of new species requires information on calls, tadpoles and reproductive behavior (Lima et al. 2007). The Allobates sp. 1 and Allobates sp. 2 can be a new species or a new record for state of Acre.

\section{Breeding grounds and calling season}

The distribution pattern of the species observed in the Lower Moa River forest is consistent with the results of Zimmerman \& Simberloff (1996) for various locations in the Amazon: many species develop in lentic aquatic environments, a smaller proportion in independent terrestrial water bodies and a few species in streams. Herein, lentic environments were also occupied by most anuran species, with greater richness found in lakes, in the lake-forming meander and in the temporary ponds on the forest edge. The temporary igarapé, a lotic environment, was less used by the anurans.

Calling activity is restricted to a few periods of the year. This seasonality is mainly conditioned by rainfall and temperature (CARDoso \& MARTINs 1987). In anuran communities, the use of various resources, including reproductive resources, is affected by seasonality (Toft \& Duellman 1979). Rainfall and the subsequent availability of water bodies is probably the most important environmental factor influencing the reproduction of frogs (HöDL 1990). Therefore, the fact that no correlation was found between anuran calling activity in the Moa River forest and monthly rainfall can be attributed to the high volume of rainfall in March, which resulted in the formation of many reproductive resources, for instance temporary water bodies (mainly in the alluvial forest). These resources enabled the calling activity of $56 \%$ of the anurans in the subsequent dry months. Nonetheless, a greater diversity index $\left(\mathrm{H}^{\prime}\right)$ was found in the rainy season, together with increased breeding activity ( $72 \%$ of the species were found calling and ovulating females were found in this season).

Particularly in environments with defined seasonality such as the Atlantic forest, anuran activity can be determined by annual temperature variations. In the Moa River forest, a small variation in temperature occurred during October 2008 to September 2009; as a result, there was no significant correlation between temperature and the number of individuals recorded. In environments where seasonality is well-defined, as in the Atlantic Forest, temperature oscillations may influence vocalization throughout the year. In the Moa River forest, there was no abrupt temperature variation between October, 2008 and September, 2009. This might explain the lack of a significant correlation between the number of species in calling activity and the month's average temperature.

\section{Use of environmental resources and breeding sites}

Most species showed no specificity for a substrate or height; species of Hylidae occupied different substrates at different heights. Most hylids are arboreal and use a wide variety of microhabitats (Duellman \& Trueb 1994). The presence of adhesive disks on these animals may confer an adaptive advantage that allows them to occupy forest environments with stratified vegetation that provides a higher number of calling sites (CARDOso et al. 1989).

Species of Sphaenorhynchus were found calling in the same site reported by Höpl (1977) in Central Amazon and also by BERTOLUCI \& RODRIGUez (2002) in the Atlantic Forest, indicating the preference of this genus for floating aquatic vegetation.

\section{Reproductive evidence}

Explosive aggregations of Rhinella marina and Trachycephalus typhonius in temporary ponds formed on the forest edge did not occur in the months of highest rainfall, corroborating the results of SAENZ et al. (2006). They suggested that explosive breeding in species that use temporary ponds are associated with one or two days of heavy rain prior to the breeding explosion (e.g., BeRNARDE 2007). Data from pitfall traps recorded many ovulating females of Chiasmocleis hudsoni in a short time, leading us to conclude that the breeding breeding pattern of this species is close to explosive, as proposed by WeLLS (1977). This pattern has been reported for other species of Microhylidae (e.g., HöDL 1990, RodRIGUEs et al. 2003).

In Central Amazon, species of Aromobatidae varied with regard to the time of recruitment of juveniles: Anomaloglossus stepheni synchronized with rainfall and Allobates sp. with the dry season (Moreira \& Lima 1991). Herein, juveniles of Allobates sp. 1 were present in both seasons, from January to August 2009. In the same study (Moreira \& Lima 1991), juveniles of Amazophrynella minuta occurred in the dry season, a pattern also found for this species in the Lower Moa River forest, where juveniles were present in the dry season, from May to August 2009. More recent data for the Adolph Ducke Reserve showed a greater abundance of juveniles in the end of the rainy season, in April and May 2008 (Menin et al. 2008). Elsewhere, studies using variation in body size and abundance of individuals indicate the occurrence of juvenile recruitment in the dry season (Aichinger 1987, Watling \& Donnelly 2002).

Fifty species of anurans were recorded in a relatively small area (256 ha) and differences in the composition of the anurofauna were detected between two different forest types (terra firme forest and alluvial forest). To sample anurans in the Amazon it is important of to use two or more sampling methods and also to consider the different forest types in this biome for a better characterization of species richness.

\section{ACKNOWLEDGEMENTS}

We thank CNPq for financial support (Process: 479225/ 2007-9), CAPES for the scholarship granted and IBAMA (SISBIO) for the collection permit (12178-1 and 12178-2). 


\section{LITERATURE CITED}

ACre (2006) Programa Estadual de Zoneamento EcológicoEconômico do Estado do Acre Fase II - Escala 1:250.000. Rio Branco, Governo do Estado do Acre, SEMA, 356p.

Aichinger M (1987) Annual activity patterns of anurans in a seasonal neotropical environment. Oecologia 71(4): 583-592.

Arzabe C (1999) Reproductive activity patterns of anurans in two different altitudinal sites within the Brazilian Caatinga. Revista Brasileira de Zoologia 16(3): 851-864. doi: 10.1590/S0101-81751999000300022

Avila-Pires TCS, Hoogmoed MS, Vitt LJ (2007) Herpetofauna da Amazônia, p. 13-43. In: Nascimento LB \& Oliveira ME (Eds.). Herpetologia no Brasil II. Belo Horizonte, Sociedade Brasileira de Herpetologia, Anolis Books, 354p.

Ayres M, Ayres MJR, Ayres DL, Santos A (2005) BioEstat 4.0 aplicações estatísticas nas áreas das ciências biológicas e médicas. Belém, Sociedade Civil Mamirauá, 324p.

Azevedo-Ramos C, Galatti U (2002) Patterns of amphibian diversity in Brazilian Amazonia: conservation implications. Biological Conservation 103(1): 103-111.

Bernarde PS (2007) Ambientes e temporada de vocalização da anurofauna no Município de Espigão do Oeste, Rondônia, Sudoeste da Amazônia - Brasil (Amphibia: Anura). Biota Neotropica 7(2): 1-6. doi: 10.1590/S1676-06032007000200010

Bernarde, P.S. 2012. Anfíbios e Répteis: Introdução ao Estudo da Herpetofauna Brasileira. Curitiba, Anolis Books, 320p.

Bernarde PS, Kokubum MNC (1999) Anurofauna do Município de Guararapes, Estado de São Paulo, Brasil (Amphibia: Anura). Acta Biológica Leopoldensia 21(1): 89-97.

Bernarde PS, Souza MB, Koкubum MNC (1999) Predation on Hyla minuta Peters, 1872 (Anura, Hylidae) by Ancylometes spp. (Araneae, Pisauridae). Biociências 7: 199-203.

Bernarde PS, Machado RA, Turci LCB (2011) Herpetofauna da área do Igarapé Esperança na Reserva Extrativista Riozinho da Liberdade, Acre - Brasil. Biota Neotropica 11(3): 117144. doi: 10.1590/S1676-06032011000300010

Bernarde PS, Albuquerque S, Miranda DB, Turci LCB (2013) Herpetofauna da floresta do baixo rio Moa em Cruzeiro do Sul, Acre - Brasil. Biota Neotropica 13(1): 220-244. doi: 10.1590/S1676-06032013000100023

Bertoluci J, Rodrigues MT (2002) Utilização de Habitats Reprodutivos e Micro-Habitats de Vocalização em uma Taxocenose de Anuros (Amphibia) da Mata Atlântica do Sudeste do Brasil. Papéis Avulsos de Zoologia 42(11): 287297. doi: 10.1590/S0031-10492002001100001

Brown JR KS, Freitas AVL (2002) Diversidade Biológica no Alto Juruá: Avaliação, Causas e Manutenção, p. 33-42. In: Cunha MC, Almeida MB (Orgs.). Enciclopédia da Floresta: O Alto Juruá: Práticas e Conhecimentos das Populações. São Paulo, Companhia das Letras, 784p.

Caldwell JP, Araújo MC (2005) Amphibian faunas of two eastern Amazonian Rainforest sites in Pará, Brazil. Occasional
Papers Sam Noble Oklahoma Museum of Natural History (16): 1-41.

Caldwell JP, Oliveira VRL (1999) Determinants of biparental care in the spotted poison frog, Dendrobates vanzolinii (Anura: Dendrobatidae). Copeia 1999: 565-575.

Campbell HW, Christman SP (1982) Field techniques for Herpetofaunal community analysis, p. 193-200. In: ScotT JR NJ (Ed.). Herpetological communities: a Symposium of the Society for the Study of Amphibians and Reptiles and the Herpetologis's League. Washington, DC, US Fish Wildlife Service, IV+239p.

CAPOBIANCO, JPR (2001) Biodiversidade na Amazônia brasileira: avaliação e identificação de áreas e ações prioritárias para a conservação, utilização sustentável e repartição de benefícios da biodiversidade brasileira. São Paulo, Ed. Estação Liberdade: Instituto Socioambiental, 540 p.

Cardoso AJ, Martins Je (1987) Diversidade de anuros durante o turno de vocalizações, em comunidade neotropical. Papéis Avulsos de Zoologia 36(23): 279-285.

Cardoso AJ, Andrade GV, Haddad CFB (1989) Distribuição espacial em comunidades de anfíbios (Anura) no sudeste do Brasil. Revista Brasileira de Biologia 49(1): 241-249.

Cardoso AJ, Vielliard J (1990) Vocalizações de anfíbios anuros de um ambiente aberto, em Cruzeiro do Sul, Estado do Acre. Revista Brasileira de Biologia 50(1): 229-242.

Caramaschi U, Niemeyer H (2003) Nova espécie do complexo de Bufo margaritifer (Laurenti, 1768) do Estado do Mato Grosso do Sul, Brasil (Amphibia, Anura, Bufonidae). Boletim do Museu Nacional 501: 1-16.

Cechin SZ, Martins M (2000) Eficiência de armadilhas de queda (pitfall traps) em amostragem de anfíbios e répteis no Brasil. Revista Brasileira de Zoologia 17(3): 729-740. doi: 10.1590/S0101-81752000000300017

Colwell RK (2013) EstimateS: Statistical estimation of species richness and shared species from samples. Version 9.1.0. Available online at: http://viceroy.eeb.uconn.edu/estimates [Accessed: 16 November 2014]

Connell JH (1978) Diversity in tropical rainforest and coral reefs. Science 199 (4335): 1302-1310. doi: 10.1126/science.199. 4335.1302

CoRn PS (1994) Straight-line drift fences and pitfall traps. of species co-occurrence, p. 118-125. In: Heyer WR, Donnely MA, McDiarmid RW, HaYer LC, Foster MS (Eds.). Measuring and monitoring biological diversity: standard methods for amphibians. Washington, DC, Smithsonian Institution Press, 364p.

Daly, DC, Silveira M (2002) Aspectos florísticos da Bacia do Alto Juruá: história botânica, peculiaridades, afinidades e importância para a conservação, p. 53-63. In: Cunha MC, Almeida MB (Orgs.). Enciclopédia da Floresta: O Alto Juruá: Práticas e Conhecimentos das Populações. São Paulo, Companhia das Letras, 784p. 
Duellman, WE (1999) Distribution Patterns of Amphibians in South America, p. 255-327. In: WE Duellman (Ed.). Patterns of Distribution of Amphibians. Baltimore, The Johns Hopkins University Press, 633p.

Duellman WE, Mendelson III JR (1995) Amphibians and reptiles from northern Departamento Loreto, Peru: Taxonomy and Biogeography. The University of Kansas Science Bulletin 55(10): 329-376.

Duellman We, Trueb L (1994) Biology of Amphibians. Baltimore, Johns Hopkins University Press, 640p.

Frost, DR (2014) Amphibian species of the world: an online reference. New York, American Museum of Natural History, v. 6.0. Available on line at: http://research.amnh.org/ herpetology/amphibia/index.html [Accessed: 16 November 2014]

GASCON C (1991) Population and community level analyses of species occurrences of Central Amazonian Rainforest tadpoles. Ecology 72(5): 1731-1746.

Haddad, CFB, Toledo LF, Prado CPA, Loebmann D, Gasparini JL, SAzıma I (2013) Guia dos Anfíbios da Mata Atlântica: Diversidade e Biologia. São Paulo, Anolis Books, 543p.

Heyer WR, Donnelly MA, Mcdiarmid RW, Hayek LC, Foster MS (1994) Measuring and monitoring biological diversity: standard methods for amphibians. Washington, DC, Smithsonian Institution Press, 364p.

Höld W (1977) Call Differences and Calling Site Segregation in Anuran Species from Central Amazonian Floating Meadows. Oecologia 28(4): 351-363.

HöLD W (1990) Reproductive diversity in Amazon lowland frogs. Fortschritte der Zoologie 38: 41-60.

Junk, WJ (1997) General aspects of floodplain ecology whit special reference to Amazonian floodplains, p. 3-17. In: JunK WJ (Ed.). The Central Amazon Floodplain. Ecology of a pulsing system. Berlin, Springer-Verlag, 526p.

Kaefer IL, Simões PI, Lima AP (2012) First record of Allobates nidicola (Anura: Dendrobatoidea) from the state of Rondônia, southwestern Amazonia, Brazil. Salamandra 48(2): 122-124.

KREBS CJ (1999) Ecological methodology. Menlo Park, Addison Wesley Longman, 620p.

Lavilla EO, Caramaschi U, Langone JA, Pombal Jr JP, Sá RO (2013) The identity of Rana margaritifera Laurenti, 1768 (Anura, Bufonidae). Zootaxa 3646: 251-264. doi: 10.11646/ zootaxa.3646.3.4

Lima AP, Magnusson We, Menin M, Erdtmann LK, Rodrigues DJ, Keller C, Hödl W (2006) Guia de sapos da Reserva Adolph Ducke - Amazônia Central. Manaus, Editora Attema, INPA, $168 p$.

Lima, AP, SAnchez DEA, Souza JRD (2007) A new Amazonian species of the frog genus Colostethus (Dendro-batidae) that lays its eggs on undersides of leaves. Copeia 2007: 114-122.

MAGURRAN A (1988) Ecological diversity and its measurement. London, Croom Helm, 179p.
Martins M, AJ Cardoso (1987) Novas espécies de hilídeos do Estado do Acre (Amphibia: Anura). Revista Brasileira de Biologia 47(4): 549-558.

May RV, Siu-Ting K, Jacobs JM, Medina-Müller M, Gagliardi G, Rodríguez LO, Donnelly MA (2009) Species diversity and conservation status of amphibians in Madre de Dios, southern Peru. Herpetological Conservation and Biology 4(1): 14-29.

Mcalecee N, Lambsheah PJD, Paterson GLJ, Gage JG (1997) BioDiversity Professional, Beta-Version. London, The Natural History Museum and The Scottish Association for Marine Sciences.

Menin M, Waldez F, Lima AP (2008) Temporal variation in the abundance and number of species of frogs in 10,000 ha of a forest in Central Amazonia, Brazil. South American Journal of Herpetology 3(1): 68-81. doi:10.2994/1808-9798(2008)3 [68:TVITAA]2.0.CO;2

Moreira G, Lima AP (1991) Seasonal patterns of juvenile recruitment and reproduction in four species of leaf litter frogs in central Amazônia. Herpetologica 47(3): 295-300.

Ribeiro AGO (1977) Clima do Estado do Acre. Boletim Geográfico 35: 112-141.

Rodrigues DJ, Lopes FS, Uetanabaro M (2003) Padrão reprotudutivo de Elachistocleis bicolor (Anura, Microhylidae) na Serra da Bodoquena, Mato Grosso do Sul, Brasil. Iheringia, Série Zoologia, 93(4): 365-371. doi: 10.1590/S0073-47212003000400003

Rodriguez LB, Cadle JE (1990) A preliminary overview of the herpetofauna of Cocha Cashu, Manu Nation Park, Peru, p. 410-425. In: Gentry AH (Ed.). Four Neotropical Rainforest. New Haven, Yale University Press, 640p.

Rodriguez LO (1992) Structure et organisation du peuplement d'anoures de Cocha Cashu, Parc National Manu, Amazonie Peruvienne. Revue d'ecologie 47(2): 151-197.

Saenz D, FitzGerald LA, Baum KA, Conner RN (2006) Abiotic Correlates of Anuran Calling Phenology: The Importance of Rain, Temperature, and Season. Herpetological Monographs 20: 6482. doi:10.1655/0733-1347(2007)20[64:ACOACP]2.0.CO;2

Santos TG, Rossa-Feres DC, Casatti L (2007) Diversidade e distribuição espaço temporal de anuros em região com pronunciada estação seca no sudeste do Brasil. Iheringia, Série Zoologia, 97(1): 37-49. doi: 10.1590/S0073-47212007000100007

Silveira M, Torezan JMD, Daly DC (2002) Vegetação e diversidade arbórea da região do Alto Juruá, p. 65-75. In: CunHA MC, Almeida MB (Orgs.). Enciclopédia da Floresta. O Alto Juruá: Práticas e Conhecimentos das Populações. São Paulo, Companhia das Letras, 784p.

SouzA, MB (2009) Anfíbios Reserva Extrativista do Alto Juruá e Parque Nacional da Serra do Divisor, Acre. Campinas, Editora do Instituto de Filosofia e Ciências Humanas, Unicamp, Série pesquisa e monitoramento participativo em áreas de conservação gerenciadas por populações tradicionais, 77p.

Toft CA, Duellmann WE (1979) Anurans of the Lower Rio Llullapichus, Amazonian Perú: a preliminary analysis of community structure. Herpetologica 35(1): 71-77. 
Vasconcelos TS, Rossa-Feres DC (2005) Diversidade, distribuição espacial e temporal de anfíbios anuros (Amphibia, Anura) na região noroeste do estado São Paulo, Brasil. Biota Neotropica 5(2): 1-14. doi: 10.1590/S1676-06032005000300010

Veloso HP, Rangel-Filho ALR, Lima JCA (1991) Classificação da vegetação brasileira, adaptada a um sistema universal. Rio de Janeiro, Instituto Brasileiro de Geografia e Estatística-IBGE, 123p.

Watling Ji, Donnelly MA (2002) Seasonal patterns of reproduction and abundance of leaf litter frogs in a Central
American rainforest. Journal of Zoology 258(2): 269-276. doi: 10.1017/S0952836902001371

WeLLS KD (1977) The social behaviour of anuran amphibians. Animal Behaviour 25: 666-693.

ZAR JH (1999) Biostatistical analysis. New Jersey, Prentice Hall, $929 \mathrm{p}$.

Zimmerman BL, Simberloff D (1996) An historical interpretation of habitat use by frogs in a Central Amazonian Forest. Journal of Biogeography 23(1): 27-46.

Submitted: 9 May 2014

Received in revised form: 19 November 2014

Accepted: 28 February 2015

Editorial responsibility: Mauricio O. Moura 